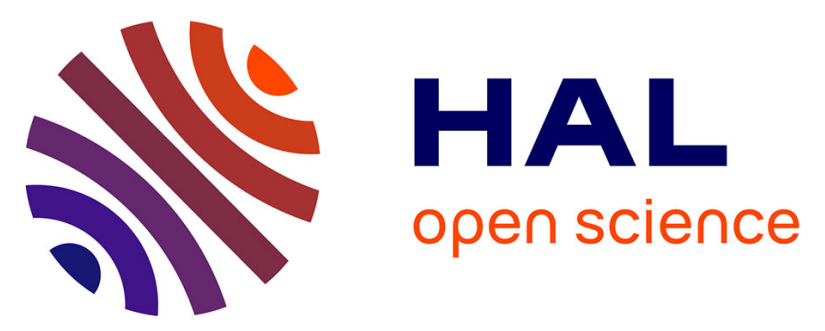

\title{
Late Triassic extensional tectonics in the northern North China Craton, insights from a multidisciplinary study of the Wangtufang pluton
}

Huabiao Qiu, Wei Lin, Michel Faure, Yan Chen, Lingtong Meng, Jipei Zeng, Zhiheng Ren, Yin Wang, Qiuli Li

\section{To cite this version:}

Huabiao Qiu, Wei Lin, Michel Faure, Yan Chen, Lingtong Meng, et al.. Late Triassic extensional tectonics in the northern North China Craton, insights from a multidisciplinary study of the Wangtufang pluton. Journal of Asian Earth Sciences, 2020, 200, pp.104462. 10.1016/j.jseaes.2020.104462 . insu-02877251

\section{HAL Id: insu-02877251 \\ https://hal-insu.archives-ouvertes.fr/insu-02877251}

Submitted on 22 Jun 2020

HAL is a multi-disciplinary open access archive for the deposit and dissemination of scientific research documents, whether they are published or not. The documents may come from teaching and research institutions in France or abroad, or from public or private research centers.
L'archive ouverte pluridisciplinaire HAL, est destinée au dépôt et à la diffusion de documents scientifiques de niveau recherche, publiés ou non, émanant des établissements d'enseignement et de recherche français ou étrangers, des laboratoires publics ou privés. 


\section{Journal Pre-proofs}

Late Triassic extensional tectonics in the northern North China Craton, insights from a multidisciplinary study of the Wangtufang pluton

Huabiao Qiu, Wei Lin, Michel Faure, Yan Chen, Lingtong Meng, Jipei Zeng, Zhiheng Ren, Yin Wang, Qiuli Li

PII: S1367-9120(20)30255-8

DOI: https://doi.org/10.1016/j.jseaes.2020.104462

Reference: JAES 104462

To appear in: Journal of Asian Earth Sciences

Received Date: 20 March 2020

Revised Date:

7 June 2020

Accepted Date:

7 June 2020

Please cite this article as: Qiu, H., Lin, W., Faure, M., Chen, Y., Meng, L., Zeng, J., Ren, Z., Wang, Y., Li, Q., Late Triassic extensional tectonics in the northern North China Craton, insights from a multidisciplinary study of the Wangtufang pluton, Journal of Asian Earth Sciences (2020), doi: https://doi.org/10.1016/j.jseaes. 2020.104462

This is a PDF file of an article that has undergone enhancements after acceptance, such as the addition of a cover page and metadata, and formatting for readability, but it is not yet the definitive version of record. This version will undergo additional copyediting, typesetting and review before it is published in its final form, but we are providing this version to give early visibility of the article. Please note that, during the production process, errors may be discovered which could affect the content, and all legal disclaimers that apply to the journal pertain.

(C) 2020 Published by Elsevier Ltd. 


\section{Late Triassic extensional tectonics in the northern North}

2 China Craton, insights from a multidisciplinary study of the

3 Wangtufang pluton

4 Huabiao Qiu ${ }^{1,2,3}$, Wei Lin ${ }^{1,3 *}$, Michel Faure², Yan Chen², Lingtong Meng ${ }^{1,3}$, Jipei Zeng ${ }^{1,3}$,

5 Zhiheng Ren ${ }^{1,3}$, Yin Wang ${ }^{1,3}$, and Qiuli Li $^{1}$

6 'State Key Laboratory of Lithospheric Evolution, Institute of Geology and Geophysics,

7 Innovation Academy for Earth Science, Chinese Academy of Sciences, Beijing100029, China

8 2Univ. Orléans, CNRS, BRGM, ISTO, UMR 7327, F-45071, Orléans, France

$9{ }^{3}$ University of Chinese Academy of Sciences, Beijing100049, China

10 *Corresponding author: (linwei@mail.iggcas.ac.cn)

14 Postal address: No. 19, Beitucheng Western Road, Chaoyang District, 100029, Beijing,

15 P.R.China 


\section{Abstract}

To better understand Late Triassic tectonic setting in the northern North China Craton (NCC), the emplacement mechanism of the Wangtufang pluton, which recorded the synmagmatic regional tectonic signature, has been investigated. Zircon U-Pb ages, and $\mathrm{Hf}$ isotopic data, and whole-rock geochemical analyses suggest that the Late Triassic Wangtufang pluton composed of

21 syenogranite and diorite is derived from partial melting of lower crust with some depleted mantle

22 components. Both the syenogranite and diorite appear isotropic. Anisotropy of magnetic

23 susceptibility and gravity studies have been carried out to characterize internal fabrics and shape

24 of the pluton. The diorite forms just thin remnants above the syenogranite. The syenogranite with

25 a series of NW-SE trending dykes intruded into the diorite and its country rocks. In the

26 syenogranite, the gently dipping magnetic foliations strike nearly parallel to the pluton border. The

27 shallow plunging magnetic lineations mainly strike NE-SW. Combining NE-SW trending 28 elongated subsurface shape with central root, unflat bottom, and moderate- to high- inward dipping

29 sidewalls, the syenogranite could be considered as a lopolith-like intrusion. The syenogranite was 30 likely emplaced by inflation of magma pulses from its central conduit and built up by floor 31 depression. Emplacement of the syenogranite was in an extensional setting, considering: (1) the

32 NE-SW striking magnetic lineation, (2) the NE-SW trending elongated subsurface pluton shape,

33 and (3) the orthogonal NW-SE striking syenogranitic dykes considered as tension gashes during

34 the NE-SW trending extension. The Wangtufang pluton provides reliable arguments to the Late

35 Triassic intracontinental extensional setting already suggested in the northern NCC.

36 Key words: North China Craton; early Mesozoic magmatism; Wangtufang pluton;

37 multidisciplinary study; Late Triassic extensional tectonics

\section{1. Introduction}


The early Mesozoic magmatism, represented by E-W trending Late Triassic alkaline

40 intrusive complexes, is conspicuous in the northern NCC. However, their tectonic and geodynamic

41 settings are still debated (Yang et al., 2012; Zhang et al., 2012; Zhao et al., 2015). Based on

42 structural observations and paleomagnetic studies, one group of researchers considers that these

43 Late Triassic granitic and syenitic plutons were due to large-scale Triassic thrusting and strike-slip

44 faulting in the northern margin of the NCC and produced in the local extensional areas by the pull-

45 apart of the strike-slip faults (e.g., Zhao et al., 2015). According to geochemical studies, another

46 group proposes that the Late Triassic alkaline complexes in the northern NCC, especially silica-

47 undersaturated syenites, occurred in an intracontinental extensional tectonic setting (e.g., Yang et

48 al., 2012; Zhang et al., 2012), implying the early timing of cratonic destruction during the Late

49 Triassic (Han et al., 2004). The Late Triassic tectonic regime is important to understand the

50 tectonic and geodynamic evolution of the NCC. However, only few small remnants of Late

51 Triassic sedimentary basins can be observed and offer little coeval structural information in the

52 northern NCC due to the intense post-Triassic tectonics (i.e., Xiabancheng basin and Niuyingzi-

53 Dengzhangzi basin in the Yanshan Fold-and-Thrust Belt (YFTB); Fig. 1; Davis et al., 2009; Meng

54 et al., 2014). Moreover, it is difficult to recognize the regional tectonic framework from these few

55 small remnant basins. Due to less impressive and controversial evidence, the nature of the Triassic

56 regime is in debate since long time with different hypotheses. Late Triassic contractional tectonics

57 was proposed according to the unconformity between Triassic and Lower Jurassic strata, and

58 Lower Jurassic syntectonic conglomerate (Zhao, 1990; Liu et al., 2012). Detrital zircon dating and

59 sedimentary studies suggest that the conformable Upper Triassic strata were deposited in an

60 extensional setting (Davis et al., 2009; Meng et al., 2014; Meng et al., 2019). Consequently, the

61 paucity of structural data makes difficult to assess the Late Triassic tectonic regime. 
During pluton emplacement, magma fabrics can potentially record information on both

63 magma dynamics and regional strain fields to which the magma was subjected (e.g., Bouchez, et

64 al., 1997; Paterson et al., 1998; Sant'Ovaia et al., 2000). The solid-state fabrics present structural

65 deformation after magma full crystallization (Paterson et al., 1989). Therefore, the fabric pattern

66 and shape of pluton are crucial to decipher the pluton emplacement process. The structural study

67 of plutons is an effective and practical way to unravel regional tectonic setting coeval with the

68 emplacement process (e.g., Bouchez, et al., 1997; De Saint Blanquat et al., 2011). Numerous

69 studies have proven that the fabrics of granitic plutons may provide signatures of the local and

70 regional constraints on the pluton emplacement (e.g., Paterson et al., 1998; De Saint Blanquat et

71 al., 2011; Lin et al., 2013b). Therefore, Late Triassic plutons from the NCC present good

72 opportunities to realize this purpose, and, accordingly, the Wangtufang pluton was chosen for this

73 study (Fig. 1). Indeed, such studies have been rarely performed on Late Triassic plutons of the

74 northern NCC. An integrated multidisciplinary investigation, including structural geology,

75 geochronology, geochemistry, Anisotropy of magnetic susceptibility (AMS), and gravity

76 modeling, has been conducted to decipher the Late Triassic tectono-magmatic setting in the

77 northern NCC. Given the correlation with other contemporaneous plutons or tectonics, the

78 proposed model may have regional implications for the Late Triassic tectonic setting in the

79 northern NCC.

\section{Geological setting}

After its assembly through the collision of the Eastern, Intermediate (or Fuping), and

82 Western blocks during the Paleoproterozoic (Zhao et al., 2001; Faure et al., 2007; Li and Zhao et

83 al., 2007; Li et al., 2012), the NCC formed a stable craton from Mesoproterozoic to Paleozoic.

84 Archaean and Paleoproterozoic gneiss, migmatites and granites were overlain by a 
85 Mesoproterozoic to Permian sedimentary cover, separated by a widespread disconformity between

86 the Middle Ordovician and Upper Carboniferous sequences (Li et al., 2016). The closure time of

87 the Paleo-Asian Ocean to the north of the NCC is still controversial. Some authors argue for a Late

88 Permian to the Early Triassic age (e.g., Windley et al. 2007; Xiao et al., 2015), whereas others

89 propose the Paleo-Asian Ocean closed during the Late Devonian, followed by the Late

90 Carboniferous-Triassic intracontinental tectonics (Xu et al., 2013; Zhao et al., 2013). In the south,

91 the NCC collided with the South China Block before the Middle Devonian (e.g., Mattauer et al.,

92 1985; Xu et al., 1986) or in the Triassic (e.g., Meng and Zhang, 1999; Hacker et al., 2000; Li et

93 al., 2010, 2011, 2017, 2018). In the YFTB, the E-W trending ductile shear zone and thick- and

94 thin-skinned folds and faults occurred progressively from the northern margin toward the interior

95 (Wang et al., 2013). The ductile shear zone concerns the E-W trending Chicheng - Fengning,

96 Fengning - Longhua, and Damiao - Niangniangmiao ductile shear zones in the north (Wang et al.,

97 2013; Zhang et al., 2014; Figure 1), and the E-W trending folds and thrusts include the Unnamed

98 fault, Malanyu anticline, and Jixian thrust fault in the south (Davis et al., 2001; Ma et al., 2007).

99 Few Triassic remnant basins and a large number of contemporaneous plutons are exposed in the

100 northern NCC (Davis et al., 2009; Zhang et al., 2012; Meng et al., 2014).

101 During the Jurassic to earliest Cretaceous, the Mongol-Okhotsk Ocean closed

102 progressively from west to east in the north of the East Asian continent (Zorin, 1999; Daoudene et

103 al., 2013). Meanwhile, the subduction of the Paleo-Pacific Ocean plate occurred in the southeast

104 of the East Asian continent (Davis et al., 2001). A large scale intra-continental deformation and

105 magmatism, traditionally referred to as the Yanshanian movement, occurred in the NCC (Davis et

106 al., 2001; Faure et al., 2012; Zhang et al., 2014; Dong et al., 2015). The YFTB is a typical

107 intracontinental orogen, formed in the northern part of the NCC (Davis et al., 2001). The thrust 
108 faults, which strike E-W in the west and NE-SW in the east, are distributed throughout the YFTB

109 (e.g., Davis et al., 2001; Faure et al., 2012; Fig. 1). As mentioned above, due to the intense

110 deformation during the Jurassic Yanshanian contractional events, only few pre-Jurassic structures

111 could be surely recognized in the YFTB (e.g., Davis et al., 2009; Zhang et al., 2012; Meng et al.,

112 2014; Zhang et al., 2014; Fig.1). In the Early Cretaceous, the NCC was dominated by extensional

113 tectonics (i.e., metamorphic core complexes (MCCs), A-type magmatism, graben or half-graben

114 basins; Li et al., 2012; Zhang et al., 2014, Lin et al., 2018).

\section{3. Structural observations}

\section{$116 \quad 3.1$ Field observations}

117 The Wangtufang pluton has a subcircular surface exposure with a radius of about $12 \mathrm{~km}$.

118 It mainly consists of syenogranite in the southwest and diorite in the northeast (Fig. 2).

119 Macroscopically, these two types of rocks (i.e., pale red syenogranite and dark gray diorite) appear

120 totally isotropic, lacking of any planar and linear structures at outcrops (Figs. 3a and 3b). The main

121 rock-forming minerals, namely, quartz, K-feldspar, plagioclase, amphibole, and biotite, are

122 generally euhedral to subhedral without obvious preferred orientation. The Wangtufang pluton

123 intrudes into foliated, even mylonitic Archaean gneiss and undeformed migmatitic granite (Lin et

124 al., 2013a; Fig. 2). In the gneiss, in spite of the strike variation of foliation, the mineral and

125 stretching lineations are consistently oriented along a NW-SE direction (Figs. 2 and 3c-3d). A

126 top-to-the SE sense of shear is indicated by sigmoidal K-feldspar porphyroclasts (Fig. 3e). The

127 gneiss is pervasively folded by the top-to-the SE shearing, indicative of strong deformation before

128 pluton emplacement. In the northwest, steep and weak foliations are developed in the migmatitic

129 granite near the contact with the diorite (Figs. 2 and 3f). A remnant of the country rocks is 
130 preserved in the southeast of the syenogranite (Fig. 2). The pluton is overlain by Cretaceous

131 pyroclastic rocks in its east (Fig. 2).

132 In the Wangtufang pluton, centimeter to ten-meter wide syenogranitic dykes extensively

133 intrude in the diorite (Fig. 2). Meter-scale dykes intruded into the diorite near the contact between

134 the syenogranite and diorite (Fig. 4a). Locally, diorite blocks are included in syenogranite dykes

135 (Fig. 4b). The contact between syenogranite and drop blocks of diorite is sharp. It can be observed

136 that numerous dykes of the syenogranite intruded into the diorite in its northeasternmost (Fig. 4c).

137 Furthermore, all dykes are steep and strike consistently NW-SE direction (Fig. 2). In the

138 syenogranite, several ten-meter xenoliths in diameter of the diorite are scattered in the syenogranite

139 (Fig. 4d). A remnant of diorite remains in the center of the syenogranite (Fig. 2). These phenomena

140 show that the diorite was dismembered by the intrusion of the syenogranite with a series of dykes

141 after the diorite had fully crystallized.

\section{$142 \quad 3.2$ Microscopic observations}

143 To determine the relationships between the minerals and magnetic fabrics, microstructures

144 are investigated in 36 sampling sites of the Wangtufang pluton (Fig. 5a). Under the microscope,

145 two textural types can be distinguished in the Wangtufang pluton. At most sites (67\%), the

146 Wangtufang pluton presents magmatic fabrics without any evidence of deformation (Figs. 5a-5c).

147 Quartz crystals are anhedral, non-deformed, and do not show signs of undulose extinction or 148 dynamic recrystallization. K-feldspars present Carlsbad twinning and marginal replacement by 149 myrmekite (Fig. 5b). The euhedral biotite flakes have a sharp extinction and are neither kinked nor

150 bent (Fig. 5c). Plagioclase grains are euhedral and exhibit Carlsbad-albite compound twinning and

151 polysynthetic twinning (Fig. 5c). Besides, at some sites (33\%), submagmatic fabrics can be also

152 observed (Fig. 5a). Millimeter-sized quartz grains show an undulose extinction, and small well- 
153 individualized quartz grains occur at the border of the coarse grains (Figs. 5d and 5e). Generally,

154 significant solid-state deformation has not been observed. The fabrics are mostly acquired in

155 magmatic state but record some submagmatic deformation.

\section{4. Geochronology and geochemistry}

\subsection{Zircon U-Pb geochronology}

Considering the paucity of available dating in this pluton, new zircon $\mathrm{U}-\mathrm{Pb}$ dating of two samples WTF5 and WTF13 was performed by a Cameca IMS 1280 large-radius SIMS at the

160 Institute of Geology and Geophysics, Chinese Academy of Sciences (IGGCAS), Beijing (Fig. 2;

161 Tab. 1). The zircon grains from these two samples are subhedral, transparent, and 50-150 $\mu \mathrm{m}$ in

162 length with aspect ratios between 1:1 and 3:1. CL images show clear oscillatory zoning (Fig. 6).

$163 \mathrm{Th} / \mathrm{U}$ ratios of Sample WTF5 vary from 0.42 to 1.12 . Twenty analyses of ${ }^{206} \mathrm{~Pb} /{ }^{238} \mathrm{U}$ and ${ }^{207} \mathrm{~Pb} /{ }^{235} \mathrm{U}$

164 results plotted on a Concordia diagram are relatively consistent, yielding a Concordia age of 209.0

$165 \pm 1.4 \mathrm{Ma}$, interpreted as the Late Triassic crystallization age of the syenogranite (Fig. 6, Tab. 1).

166 This age is in agreement with previous age at $207 \pm 1 \mathrm{Ma}$ (Liu et al., 2012; Fig. 2). Th/U ratios of

167 Sample WTF13 range from 0.38 to 1.50 . Nineteen analyses of ${ }^{206} \mathrm{~Pb} /{ }^{238} \mathrm{U}$ and ${ }^{207} \mathrm{~Pb} /{ }^{235} \mathrm{U}$ results

168 show a Concordia age of $208.8 \pm 1.8 \mathrm{Ma}$ (Fig. 6, Tab. 1). It corresponds to the Late Triassic

169 emplacement age of the diorite, older than a previous age at $191 \pm 1 \mathrm{Ma}$ (Liu et al., 2012; Fig. 2).

170 The ages of the syenogranite and diorite are the same within errors.

\section{$171 \quad 4.2$ Major and trace elements analyses}

172 Analyses of whole-rock major and trace elements were carried out at the IGGCAS. Major

173 elements were analysed by X-ray spectrometry. Analytical precision is estimated at $1-5 \%$ for

174 major elements. Trace elements were determined by inductively coupled plasma mass

175 spectrometry (ICP-MS). The major- and trace-element data are documented in Tab. 2. The 
176 syenogranite samples have high $\mathrm{SiO}_{2}$ contents ranging from 75.05 to $77.01 \mathrm{wt} \%$. All samples are

177 relatively high in $\mathrm{Al}_{2} \mathrm{O}_{3}\left(12.44-13.34\right.$ wt \%), $\mathrm{Na}_{2} \mathrm{O}(3.51-4.06 \mathrm{wt} \%)$ and total alkalis $\left(\mathrm{K}_{2} \mathrm{O}+\right.$

$178 \mathrm{Na}_{2} \mathrm{O}, 8.42-8.91$ wt \%), with $\mathrm{Na}_{2} \mathrm{O} / \mathrm{K}_{2} \mathrm{O}$ ratios of $0.71-0.84$. They are low in $\mathrm{P}_{2} \mathrm{O}_{5}(0.02-0.04$ wt

$179 \%)$ and $\mathrm{TiO}_{2}(0.12-0.19 \mathrm{wt} \%)$ abundances, and have $\mathrm{Mg}$ number \# of 6.76-17.73. In the total

180 alkali versus silica diagram (Fig. 7a), all samples plot in granite field. The diorite displays a $\mathrm{SiO}_{2}$

181 abundance of 51.88-56.31 wt \%. It is characterized by a high $\mathrm{Al}_{2} \mathrm{O}_{3}$ content (15.78-19.66 wt \%),

182 a wide $\mathrm{K}_{2} \mathrm{O}$ range of $1.46-3.50$ wt $\%$ and total alkalis $\left(\mathrm{K}_{2} \mathrm{O}+\mathrm{Na}_{2} \mathrm{O}, 6.68-8.16\right.$ wt \%), with

$183 \mathrm{Na}_{2} \mathrm{O} / \mathrm{K}_{2} \mathrm{O}$ ratios of $1.33-2.97$. They have relatively high $\mathrm{Fe}_{2} \mathrm{O}_{3}^{\mathrm{T}}(7.77-9.14$ wt \%) and low $\mathrm{MgO}$

$184(2.52-3.63 \mathrm{wt} \%)$ contents, with $\mathrm{Mg} \#$ of 30.67-51.97. The samples plot in the monzodiorite and

185 monzonite fields in the total alkali versus silica diagram (Fig. 7a). Both the syenogranite and the

186 diorite are peraluminous (Fig. 7b) and can be categorized as high-K calc-alkaline series rocks (Fig.

187 7c).

The syenogranite and the diorite have total rare Earth element contents ( $\sum$ REE) varying over 29.84-240.38 ppm, and 169.96-414.57 ppm, respectively, and both display right-dipping

190 chondrite-normalized REE patterns (Fig. 8a). Their $\sum$ LREE/ $\sum$ HREE ratios are 5.92-15.17 and

$1916.28-10.25$, respectively. The syenogranite displays $(\mathrm{La} / \mathrm{Yb})_{\mathrm{N}}$ and $(\mathrm{Gd} / \mathrm{Yb})_{\mathrm{N}}$ ratios of $3.21-15.81$ 192 and $0.74-1.26$ with high negative Eu anomalies $\left(\mathrm{Eu} / \mathrm{Eu}^{*}=0.16-0.54\right)$, whereas the diorite shows $193(\mathrm{La} / \mathrm{Yb})_{\mathrm{N}}$ and $(\mathrm{Gd} / \mathrm{Yb})_{\mathrm{N}}$ ratios of 9.76-14.12 and 1.87-5.03 with low negative Eu anomalies $194\left(\mathrm{Eu} / \mathrm{Eu}^{*}=0.64-0.94\right)($ Fig. 8a). In the primitive mantle-normalized variation diagrams (Fig. 8b), 195 the syenogranite and the diorite samples are both enriched in large-ion lithophile elements (LILE) 196 relative to high field strength elements (HFSE). Their REE and trace element patterns are similar 197 to the contemporaneous Dushan batholith to its south (Ye et al., 2014, Fig. 1). 
200 isotopic analyses. It was carried out in situ on a Neptune multi-collector ICP-MS equipped with a

201 Geolas-193 laser ablation system at IGGCAS. Results for in situ Hf isotope analyses of zircons

202 are shown in Fig. 9 and Tab. 3. Zircons from the syenogranite (WTF5) have variable Hf isotopic 203 compositions, ${ }^{176} \mathrm{Hf} /{ }^{177} \mathrm{Hf}$ ratios between 0.282377015 and $0.282469207, \varepsilon \mathrm{Hf}(\mathrm{t})$ values between -

2049.78 and -6.54 , and two-stage depleted mantle Hf model $\left(\mathrm{t}_{\mathrm{DM} 2}\right)$ ages between 1840.9 and 1635.3

205 Ma. Zircons from the diorite (WTF13) have ${ }^{176} \mathrm{Hf} / 177 \mathrm{Hf}$ ratios between 0.282555378 and

2060.282665470 , a range of $\varepsilon \mathrm{Hf}(\mathrm{t})$ values varying from -3.42 to -0.01 , and two-stage depleted mantle

207 Hf model $\left(\mathrm{t}_{\mathrm{DM} 2}\right)$ ages between 1439.9 and 1205.6 Ma. Magmatic zircons from the Wangtufang

208 pluton exhibit similar $\varepsilon \mathrm{Hf}(\mathrm{t})$ values from -13.69 to 3.94, and two-stage depleted mantle Hf model

$209\left(t_{\mathrm{DM} 2}\right)$ ages from 1582 to $950 \mathrm{Ma}$ in the contemporaneous plutons (Yang et al., 2012; Zhang et al.,

210 2012; Ye et al., 2014; Xiong et al., 2017).

\section{5. Anisotropy of magnetic susceptibility}

Field and microscopic observations suggest that both planar and linear fabrics cannot be

213 directly observed in the Wangtufang pluton. Magnetic fabrics can often record the fabric elements

214 of anisotropic rocks where macro and microscopic features fail to do it (Archanjo et al., 1994;

215 Bouchez and Gleizes, 1995; Bouchez et al., 1997). In order to assess the fabric elements, an AMS

216 study has been carried out. Two hundred and four cores from 36 sites have been sampled for AMS

217 measurements in the Wangtufang pluton, 20 in the syenogranite and 16 in the diorite. The 218 measurements are realized in the Laboratory of Paleomagnetism and Chronology of IGGCAS. A 219 total of 204 cores from 36 sampling sites were cut into cylindrical specimens of $2.2 \mathrm{~cm}$ in length 220 and $2.5 \mathrm{~cm}$ in diameter. The anisotropy magnetic susceptibility and the bulk susceptibility were 221 measured with a KLY4 susceptometer. The mean orientation of three principal axes of the AMS 
222 ellipsoid $\left(\mathrm{K}_{1} \geq \mathrm{K}_{2} \geq \mathrm{K}_{3}\right)$, the shape parameter $(\mathrm{T})$, and the anisotropy degree $\left(\mathrm{P}_{\mathrm{J}}\right)$ were calculated

223 by the ANISOFT package (Jelinek, 1981). The magnetic mineralogy was investigated to identify

224 the magnetic susceptibility carriers by several methods, including: (1) Isothermal Remanent

225 Magnetization (IRM); (2) thermomagnetic (K-T) curves, and (3) hysteresis loops.

\section{$226 \quad 5.1$ Magnetic mineralogy}

227 The histogram of mean magnetic susceptibility, $\mathrm{K}_{\mathrm{m}}=\left(\mathrm{K}_{1}+\mathrm{K}_{2}+\mathrm{K}_{3}\right) / 3$, displays a large

228 range of values in 36 sites, from 90 to $95,900 \times 10^{-6}$ SI (Fig. 10a and Tab. 4). In the diorite, all 16

229 sites exhibit $\mathrm{K}_{\mathrm{m}}$ values higher than $7,000 \times 10^{-6}$ SI $\left(7,540\right.$ to $\left.95,900 \times 10^{-6} \mathrm{SI}\right)$, demonstrating the

230 predominance of ferromagnetic minerals. In the syenogranite, $K_{m}$ mainly varies from about 90 to

$23115,400 \times 10^{-6} \mathrm{SI}$, and 7 out of 20 sites show $\mathrm{K}_{\mathrm{m}}$ values lower than $500 \times 10^{-6} \mathrm{SI}$, implying that the

232 paramagnetic minerals (biotite) may be the main carriers of the magnetic susceptibility (e.g.,

233 Tarling and Hrouda, 1993). In 13 out of 20 sites, $\mathrm{K}_{\mathrm{m}}$ values are higher than $500 \times 10^{-6}$ SI, suggesting

234 the presence of ferromagnetic minerals. It seems that both paramagnetic and ferromagnetic

235 minerals are the contributors to the magnetic fabrics in the syenogranite.

236 All hysteresis curves of six representative samples display nonlinear variations (Figs. 11a-

237 11c). Sudden saturation of the isothermal magnetic remanence below $300 \mathrm{mT}$ occurs in all samples

238 (Figs. 11d-11f). Thermomagnetic measurements show a rapid drop of magnetic susceptibility at $239 \sim 580^{\circ} \mathrm{C}$ (Figs. 11g-11i). All these results suggest that magnetite is likely an overwhelming 240 contributor to the magnetic carriers in the Wangtufang pluton despite the presence of biotite. The

241 ratios of hysteresis parameters $\mathrm{Mr} / \mathrm{Ms}$ and $\mathrm{Hcr} / \mathrm{Hc}$ display the mean grain size of the magnetite of

242 the analyzed samples is within the pseudo-single domain (PSD) zone (Dunlop, 2002; Fig. 12),

243 indicating that the principal axes of the magnetic susceptibility ellipsoid $\left(\mathrm{K}_{1}\right.$ and $\mathrm{K}_{3}$ measured in 
244 this study) correspond to the major morphological axes of minerals, representing magnetic

245 lineation and the pole of magnetic foliation, respectively.

246 More than $92 \%$ of the sampled sites display an anisotropy degree $\left(\mathrm{P}_{\mathrm{J}}\right)$ lower than 1.2 (Figs.

$24710 \mathrm{~b}$ and 10c), concordant with the magmatic fabrics recognized by microscopic observations, and

248 the remaining sites come from the diorite, implying that their higher $\mathrm{P}_{\mathrm{J}}$ value may be due to the

249 high concentration of magnetite (Cruden, et al., 1999). The shape parameter (T) mainly ranges

250 between -0.551 and 0.829 , showing a dominant oblate shape $(\sim 86 \%)$ for magnetic fabrics (Figs.

251 10c and 10d). Obvious correlations between $\mathrm{P}_{\mathrm{J}}, \mathrm{T}$, and $\mathrm{K}_{\mathrm{m}}$ is lacking, implying that AMS varies

252 independently from the magnetic minerals (Borradaile and Henry, 1997; Figs. 10b-10d).

\subsection{AMS results}

The site-average orientation with corresponding 95\% confidence level ( $\alpha_{95 \max }$ and $\left.\alpha_{95 \min }\right)$

256 larger than $25^{\circ}$, the direction of the corresponding magnetic axis is considered as poorly defined,

257 whereas it is considered as well-defined or reliable when lower than $25^{\circ}$. More than $78 \%$ of the

258 AMS sites are well defined for both $\mathrm{K}_{1}$ and $\mathrm{K}_{3}$. The magnetic fabrics were mapped throughout the

259 Wangtufang pluton (Fig. 14).

260 At the map scale, the magnetic foliations in the diorite strike subparallel to the pluton

261 boundary and dip inward at variable angles (Fig. 14a). The magnetic lineations are highly scattered

262 with variable dips (Fig. 14b). This may be due to an overprint by the late-stage tectonomagmatism.

263 Instead, in the syenogranite, both the magnetic foliations and lineations are highly grouped (Fig.

264 14a). Magnetic foliations, also parallel to the pluton boundary, display a concentric arrangement.

265 The majority of specimen (14 out of 20 sites) show subhorizontal foliations with dip angles ranging

266 from $3^{\circ}$ to $40^{\circ}$. Specimens from six sites have moderately steep magnetic foliations (dip angles 
267 ranging from $45^{\circ}$ to $70^{\circ}$ ). These sites are almost near the contacts with the country rock and the

268 diorite. The magnetic lineations are all horizontal to subhorizontal (mainly $\sim 9^{\circ}$ to $29^{\circ}$ ) and have

269 nearly constant NE-SW plunges (Fig. 14b).

270 6. Gravity modeling

271 Gravity modeling has been long proved its efficiency to constrain the geometry and

272 possible feeder zones of pluton (e.g., Vigneresse et al., 1990; Améglio and Vigneresse, 1999; Lin

273 et al., 2013b). We carried out a gravity study to characterize the shape of the Wangtufang pluton

274 at depth.

$275 \quad 6.1$ Residual Bouguer anomaly and 2D modeling

276 The short wavelengths of the gravity anomaly originate from upper crust (down to a few

277 kilometers). The long wavelengths of the gravity anomaly, which reflect the deep structures, must

278 be removed from the complete Bouguer anomaly to highlight the Wangtufang pluton related

279 anomalies. Available Bouguer anomaly map (1: 200,000) in the Wangtufang pluton and its

280 surrounding area was derived from the Chinese regional gravity survey. A regional lower-

281 resolution $\left(2^{\prime} \times 2^{\prime}\right)$ Bouguer grid acquired from the International Gravimetric Bureau database

282 (Bonvalot et al., 2012). The long wavelengths of the gravity anomaly were extracted using a 200

$283 \mathrm{~km}$ low-pass Butterworth filter from a lower-resolution $\left(2^{\prime} \times 2^{\prime}\right)$ Bouguer grid after several attempts.

284 The residual Bouguer anomaly map was obtained from the complete Bouguer anomaly by

285 subtracting the filtered regional Bouguer anomaly related to the long wavelengths (Fig. 15a).

286 2D gravity modeling was also performed to characterize the geometry of the Wangtufang

287 pluton. To build these models, several constraints have been taken into account, including (1)

288 geological contacts, lithological units, and structural data from geological maps and our field

289 observations; (2) geometrical constraints, derived from indirect analysis of gravity anomaly, and 
290 (3) densities of geological units, determined by the laboratory measurements. The residual gravity

291 anomaly has been modelled along three profiles across the center of the pluton (Fig. 15b).

$292 \quad 6.2$ Results

293 In the residual Bouguer gravity anomaly map, the Wangtufang pluton displays a NE-SW

294 trending elongated negative anomaly with a highest value in its center (Fig. 15a). The negative

295 anomalies decrease, even change into positive anomalies outwards. Particularly, the diorite shows

296 a less negative anomaly in its northwest and a higher positive anomaly in its southeast, suggesting

297 its thin thickness. The Wangtufang pluton becomes thinner outwards, presenting an overall funnel-

298 shaped geometry. The country rocks display high positive anomalies in its east. To the southwest,

299 the country rocks show a high negative anomaly, indicating the possible continuity of the pluton

300 underlain the country rocks. The highest negative anomaly is located in its northwest due to a large

301 area of Archaean migmatitic granite. Three 2D modeling profiles image the detailed geometry of

302 the two major intrusions (Fig. 15b), revealing (1) a thin thickness of the diorite that overlies the

303 syenogranite; (2) a maximal thickness of about $4 \mathrm{~km}$ in the center of the syenogranite which

304 progressively decreases outwards; (3) a slightly NE-SW trending elongated subsurface shape of

305 the syenogranite with inward dipping sidewalls.

306 7. Discussion

$307 \quad 7.1$ Magma sources of the Wangtufang pluton

308 Both high $\mathrm{SiO}_{2}$ syenogranite and relatively low $\mathrm{SiO}_{2}$ diorite are characterized by low $\mathrm{MgO}$, 309 enrichment in LREE and LILE, and depletion in HREE and HFSE, with negative Eu anomalies

310 (Figs. 7 and 8), suggesting that they mainly derived from partial melting of ancient lower crust.

311 However, their in-situ zircon two-stage depleted mantle $\mathrm{Hf}$ model ages $\left(\mathrm{t}_{\mathrm{DM} 2}\right)$ are both Proterozoic,

312 ranging from $\sim 1.840$ to $1.635 \mathrm{Ga}$ and $\sim 1.439$ to $1.205 \mathrm{Ga}$, respectively (Fig. 9). Considering that 
313 the Wangtufang pluton intrudes into Archaean gneiss and migmatitic granite $(>2.5 \mathrm{Ga})$, the

314 sources should be derived from the partial melting of Archean TTG in the lower crust with a

315 contribution from a depleted mantle source. The $\varepsilon_{\mathrm{Hf}}(\mathrm{t})$ values for the syenogranite range from -

3169.78 to -6.54 and those of the diorite from -3.42 to -0.01 (Fig. 9). Although the diorite was mainly

317 derived from melting of ancient lower crust, $\varepsilon_{\mathrm{Hf}}(\mathrm{t})$ values of the diorite are much higher than

318 normal crustal melting (Fig. 9), requiring some input of depleted asthenospheric mantle

319 components. The $\varepsilon_{\mathrm{Hf}}(\mathrm{t})$ values of the syenogranite are higher than those of the Archean lower crust

320 (-28 -13; Jiang et al., 2013). It suggests that the syenogranite has a contribution from an enriched

321 subcontinental lithospheric mantle. Therefore, the Wangtufang pluton was mainly derived from

322 partial melting of the ancient lower crust of the NCC with some involvements of enriched

323 subcontinental lithospheric mantle and depleted asthenospheric mantle components. Coeval with

324 the Wangtufang pluton, Late Triassic silica-undersaturated syenites in the alkaline complexes in

325 the northern NCC were derived from partial melting of an enriched lithospheric mantle, coupled

326 with crustal assimilation and crystal fractionation in an intracontinental extensional setting (i.e.,

327 rift; Yang et al., 2012). Its similarity with the contemporaneous alkaline complexes may indicate

328 an asthenosphere-lithospheric mantle interaction in the northern NCC during the Late Triassic

329 (Yang et al., 2012; Zhang et al., 2012). Briefly, the Wangtufang pluton was derived from the

330 mixing of magmas from asthenospheric upwelling-induced melting of subcontinental lithospheric

331 mantle and ancient lower crust during an intracontinental extensional setting.

$332 \quad 7.2$ Emplacement model

333 Geochronology data suggest that both the syenogranite and the diorite were emplaced in

334 the Late Triassic (both at $\sim 209$ Ma; Fig. 6). Concerning the fabric pattern of the diorite, magnetic

335 foliations show variable dip angles and scattered magnetic lineations, and this may be due to the 
336 later intrusion of the syenogranite (Fig. 14). The border-parallel magnetic foliations are usually

337 considered as a consequence of magma inflation during the intrusion. Gravity modeling reveals

338 thin remnants of diorite, which are close to the roof of the syenogranite (Fig. 15). Furthermore,

339 field observations indicate that numerous syenogranite dykes intruded into the diorite with sharp

340 contact and dismembered the diorite after its fully crystallization (Fig. 4). As the fabric pattern

341 seems to be modified, it is difficult to retrace the emplacement process of the diorite, therefore, we

342 shall focus on the emplacement of the syenogranite.

343 In the syenogranite, the current exposure is close to the roof of the pluton due to the

344 covering of the diorite remnants (Fig. 15). The mostly subhorizontal magnetic foliations, roughly

345 parallel to the contact, develop near the roof (Fig. 14a). Bouguer gravity anomaly reveals a NE-

346 SW trending elongated subsurface shape with an overall funnel-shaped geometry, an unflat

347 bottom, and moderate- to high- inward dipping sidewalls (Fig. 15). The root of the syenogranite

348 as a feeder zone is located in its center. Thus, it might be estimated as a lopolith-like intrusion (Fig.

349 16). Considering the lack of significant emplacement-related ductile deformation in the country

350 rocks, the syenogranite with a concentric fabric pattern could emplace by the inflation of the

351 magma from its central feeder zone and the pluton is built up by floor depression (Fig. 16). The

352 subhorizontal magnetic fabrics could have developed by magmatic flow subparallel to a roof,

353 represented by the floor of the diorite (e.g., McNulty et al., 2000). A dominant gentle magnetic

354 fabric could be formed by flattening of magma mush against its roof, driven by later magma pulses

355 (McNulty et al., 2000). The arrivals of later magma batches resulted in downward inflation of

356 magma chamber against the roof. Floor depression occurred and created space for the pluton

357 building (Fig. 16). Close to the pluton, the country rocks were pushed aside and it resulted in the

358 border-parallel foliations in the surrounding gneiss (Fig. 2). We suggest that the diorite made a 
359 first intrusion, probably with a thin thickness, and then the syenogranite intruded and possibly

360 dismembered the former with a series of dykes after the diorite had fully crystallized (Fig. 16).

$361 \quad 7.3$ Relationships between the pluton emplacement and regional tectonics

362 The microstructures observed in the Wangtufang pluton are typical of magmatic or sub

363 magmatic fabrics that developed during, or just after, the full crystallization of the magma.

364 However, the lack of significant emplacement-related ductile deformation in both the pluton and 365 its country rocks does not preclude that a regional tectonic event, dominated by brittle deformation

366 occurred during the Wangtufang pluton emplacement. The syenogranite intruded the diorite after

367 its full crystallization as shown by the dyke swarm containing diorite xenoliths (Fig. 4b). All the

368 syenogranitic dykes are steeply dipping and striking NW-SE. We interpret these syenogranite

369 dykes as tension gashes developed in the brittle upper crust, and controlled by a NE-SW stretching.

370 This view implies a possible NE-SW trending regional extension (Fig. 16).

371 Moreover, the plutons shape and internal fabric can record some increments of the regional

372 strain to which the magma was subjected (e.g., Paterson et al., 1998; Sant'Ovaia et al., 2000).

373 Because mineral fabrics are easily reset, they reflect only the last strain increment developed in

374 soft material such as magmatic rocks before their full crystallization. Furthermore, without any

375 regional strain or pre-existing structural control, the magmatic lineation that reflects the magma

376 flow within the pluton would have variable orientations and plunges (e.g., Paterson, 1989; Liu et

377 al., 2018). Thus, we argue that the syenogranite, presenting a general NE-SW magnetic lineation,

378 may have recorded a NE-SW trending regional extension (Fig. 16). Meanwhile, the pluton growth

379 could have been guided by the NE-SW trending regional tectonic regime, suggested by a NE-SW

380 trending elongated subsurface shape of the pluton (Fig. 15a). 

of Archaean TTG in the lower crust with a contribution from a depleted mantle source. This feature is consistent with the geochemical characteristics of the E-W trending alkaline intrusive

384 complexes along the northern NCC (Zhang et al., 2012; Fig. 17). Especially, the silicaundersaturated syenites comply with a Late Triassic intracontinental extensional setting after the final formation of the Central Asian Orogenic Belt (Yang et al., 2012; Fig. 17). Besides, a NESW trending regional extension in the northern NCC has been documented in the Sonid Zuoqi MCC in the vicinity of the Solonker zone (Davis et al., 2004; Fig. 17). The ${ }^{40} \mathrm{Ar} /{ }^{39} \mathrm{Ar}$ ages of muscovite in the detachment fault were 224 208 Ma. Detrital zircon dating and sedimentological studies of these basin remnants showed a fining and deepening upward depositional system as well as abundant volcaniclastic rocks from the conformable Upper Triassic to Lower Jurassic strata,

392 suggesting a Late Triassic extensional tectonic setting (Davis et al., 2009; Meng et al., 2014; Fig.

393 1). The emplacement of the Wangtufang pluton provides new structural constraints on the Late

394 Triassic NE-SW trending extensional setting in the northern NCC.

\section{Conclusions}

A multidisciplinary study, including geochronology and geochemistry, field and 397 microscopic observations, anisotropy of magnetic susceptibility (AMS), and gravity investigation, 398 has been carried out to characterize the emplacement mode and tectonic setting of the Late Triassic 399 Wangtufang pluton. These results reveal that: (1) both the syenogranite and the diorite in the 400 Wangtufang pluton are derived from the partial melting of the lower crust with a contribution from 401 a depleted mantle source; (2) the diorite, represented just by thin remnants, was intruded and 402 dismembered by the later syenogranite intrusion coeval with a NW-SE trending dyke swarm after 403 the diorite full crystallization; (3) the syenogranite, a lopolith-like intrusion, emplaced by the 
404 inflation of magma batches from a conduit in its center, and the emplacement space was mainly

405 created by floor depression for the pluton building; (4) if the consistently NW-SE striking dykes

406 may be considered as tension gashes, the Wangtufang pluton emplaced in a NE-SW trending

407 regionally extensional tectonic setting, providing more reliable arguments to the Late Triassic

408 intracontinental extensional setting already suggested in the northern NCC.

\section{Acknowledgements}

This work has been financially supported by the National Key R\&D Program of China

411 (2016YFC0600102 and 2016YFC0600401) and the NSFC (91855212, 91755205, and 41472193).

412 Prof. Sanzhong Li and two anonymous reviewers together with the editors are very much thanked

413 for their constructive comments and suggestions, which lead to a great improvement of our

414 manuscript.

\section{References}

416 Améglio, L., Vigneresse, J.L., 1999. Geophysical imaging of the shape of granitic intrusions at

417 depth: a review. Geological Society, London, Special Publications 168 (1), 39-54. https://doi.org/10.1144/GSL.SP.1999.168.01.04

419 Archanjo, C.J., Launeau, P., Bouchez, J.L., 1994. Magnetic fabrics vs. magnetite and biotite shape fabrics of the magnetite-bearing granite pluton of Gameleiras (Northeast Brazil). Physics of the Earth and Planetary Interiors 89 (1-2), 63-75. https://doi.org/10.1016/0031- 9201(94)02997-P

423 Blanquat, M.D.S., Horsman, E., Habert, G., Morgan, S., Vanderhaeghe, O., Law, R., Tikoff, B., 424 2011. Multiscale magmatic cyclicity, duration of pluton construction, and the paradoxical relationship between tectonism and plutonism in continental arcs. Tectonophysics 500 (1-4), 20-33. https://doi.org/10.1016/j.tecto.2009.12.009 
427

428

429

430

431

432

433

434

435

436

437

438

439

440

441

442

443

444

445

446

447

448

449

Bonvalot, S., Balmino, G., Briais, A., Kuhn, M., Peyrefitte, A., Vales, N., Biancale, R., et al., 2012. World gravity map. (1:50000000 map), BGI-CGMWCNES-IRD, Paris.

Borradaile, G.J., Henry, B., 1997. Tectonic applications of magnetic susceptibility and its anisotropy. Earth-Science Reviews 42 (1-2), 49-93. https://doi.org/10.1016/S00128252(96)00044-X

Bouchez, J.L., Gleizes, G., 1995. Two-stage deformation of the Mount-Louis-Andorra granite pluton (Variscan Pyrenees) inferred from magnetic susceptibility anisotropy. Journal of the Geological Society 152 (4), 669-679. https://doi.org/10.1144/gsjgs.152.4.0669

Bouchez, J.L., Hutton, D., Stephens, W.E., 1997. Granite is Never Isotropic: An Introduction to AMS Studies of Granitic Rocks. Granite: From Segregation of Melt to Emplacement Fabrics (pp. 95-112). Paris: Springer Science and Business Media. https://doi.org/10.1007/978-94-017-1717-5_6

Castro, A., 1987. On granitoid emplacement and related structures: A review. Geologische Rundschau 76 (1), 101-124. https://doi:10.1007/BF01820576

Cruden, A. R., Tobisch, O. T., Launeau, P., 1999. Magnetic fabric evidence for conduit-fed emplacement of a tabular intrusion: Dinkey Creek Pluton, central Sierra Nevada batholith, California. Journal of Geophysical Research: Solid Earth 104 (B5), 1051110530. https://doi:10.1029/1998jb900093

Davis, G.A., Meng, J.F., Cao, W.R., 2009. Triassic and Jurassic tectonics in the eastern Yanshan belt, North China: insights from the controversial Dengzhangzi Formation and its neighboring units. Earth Science Frontiers 16 (3), 69-86. https://doi.org/10.1016/S18725791(08)60090-1

Davis, G.A., Xu, B., Zheng, Y.D., Zhang, W.J., 2004, Indosinian extension in the Solonker 
suture zone: the Sonid Zuoqi metamorphiccore complex, Inner Mongolia, China. Earth Science Frontiers 11 (3), 135-144. https://doi.org/ 10.1007/BF02873097

452

Davis, G.A., Zheng, Y.D., Wang, C., 2001. Mesozoic tectonic evolution of the Yanshan fold and thrust belt, with emphasis on Hebei and Liaoning provinces, northern China. In: Hendrix, M.S., Davis, G.A. (Eds.), Paleozoic and Mesozoic tectonic evolution of central Asia: From continental assembly to intracontinental deformation, Boulder, Colorado. Geological Society of America Memoir 194, 171-197.

Daoudene, Y., Ruffet, G., Cocherie, A., Ledru, P., Gapais, D., 2013. Timing of exhumation of the Ereendavaa metamorphic core complex (north-eastern Mongolia) U-Pb and ${ }^{40} \mathrm{Ar} /{ }^{39} \mathrm{Ar}$ constraints. Journal of Asian Earth Sciences 62, 98-116. https://doi.org/10.1016/j.jseaes.2011.04.009

De Saint Blanquat, M., Horsman, E., Habert, G., Morgan, S., Vanderhaeghe, O., Law, R., Tikoff, B., 2011. Multiscale magmatic cyclicity, duration of pluton construction, and the paradoxical relationship between tectonism and plutonism in continental arcs. Tectonophysics 500 (1-4), 20-33. https://doi.org/10.1016/j.tecto.2009.12.009

Dong, S., Zhang, Y., Zhang, F., Cui, J., Chen, X., Zhang, S., Miao, L., Li, J., Shi, W., Li, Z., Huang, S., Li, H., 2015. Late Jurassic-Early Cretaceous continental convergence and intracontinental orogenesis in East Asia: a synthesis of the Yanshan revolution. Journal of Asian Earth Sciences 114, 750-770. https://doi.org/10.1016/j.jseaes.2015.08.011

Dunlop, D.J., 2002. Theory and application of the day plot (Mrs/Ms versus $\mathrm{Hcr} / \mathrm{Hc}) 1$. Theoretical curves and tests using titanomagnetite data. Journal of Geophysical Research 107 (B3), 2056. https://doi.org/10.1029/2001JB000487

Faure, M., Lin, W., Chen, Y., 2012. Is the Jurassic (Yanshanian) intraplate tectonics of North 
473

474

475

476

477

478

479

480

481

482

483

484

485

486

487

488

489

490

491

492

493

494

495

China due to westward indentation of the NCC? Terra Nova 24 (6), 456-466. https://doi.org/10.1111/ter.12002

Faure, M., Trap, P., Lin, W., Monié, P., Bruguier, O., 2007. Polyorogenic evolution of the Paleoproterozoic Trans-North China Belt, new insights from the in LüliangshanHengshan-Wutaishan and Fuping massifs. Episodes Journal of International Geoscience, Seoul National University 30 (2), 95-106.

Hacker, B.R., Ratschbacher, L., Webb, L., McWilliams, M.O., Ireland, T., Calvert, A., Dong, S., Wenk, H., Chateigner, D., 2000. Exhumation of ultrahigh-pressure continental crust in east central China: Late Triassic-Early Jurassic tectonic unroofing. Journal of Geophysical Research: Solid Earth 105 (B6), 13339-13364. https://doi.org/10.1029/2000JB900039

Jelinek, V., 1978. Statistical processing of anisotropy of magnetic susceptibility measured on groups of specimens. Studia Geophysica et Geodaetica 22 (1), 50-62. https://doi.org/10.1007/BF01613632

Jelinek, V., 1981. Characterization of the magnetic fabric of rocks. Tectonophysics 79 (3-4), 6367. https://doi.org/10.1016/0040-1951(81)90110-4

Jiang, N., Guo, J., Chang, G., 2013. Nature and evolution of the lower crust in the eastern North China craton: A review. Earth-Science Reviews 122, 1-9.

Li, C., Zhang, C., Cope, T. D., Lin, Y., 2016. Out-of-sequence thrusting in polycyclic thrust belts: an example from the Mesozoic Yanshan belt, North China Craton. Tectonics 35, 2082-2116. https://doi.org/10.1002/2016TC004187

Li, S.Z., Kusky, T.M., Zhao, G.C., Liu, X.C., Wang, L., Kopp, H., Hoernle, K., Zhang, G.W., Dai, L.M., 2011. Thermochronological constraints on Two-stage extrusion of HP/UHP 
terranes in the Dabie-Sulu orogen, east-central China. Tectonophysics 504, 25-42.

Li, S.Z., Kusky, T.M., Zhao, G.C., Liu, X.C., Zhang, G.W., Kopp, H., Wang, L., 2010. Twostage Triassic exhumation of HP-UHP terranes in the Dabie orogen of China: constraints from structural geology. Tectonophysics 490, 267-293.

Li, S.Z., Jahn, B.M., Zhao, S.J., Dai, L.M., Li, X.Y., Suo, Y.H., Guo, L.L., Wang, Y.M., Liu, X.C., Lan, H.Y., Zhou, Z.Z., Zheng, Q.L., Wang, P.C., 2017. Triassic southeastward subduction of North China Block to South China Block: insights from new geological, geophysical and geochemical data. Earth-Science Reviews 166, 270-285.

Li, S.Z., Zhao, G.C., 2007. SHRIMP U-Pb zircon geochronology of the Liaoji Granitoids: constraints on the Paleoproterozoic Jiao-Liao-Ji belt in the eastern block of the North China craton. Precambrian Research 158 (1-2), 1-16.

Li, S.Z., Zhao, G.C., Dai, L.M., Liu, X., Zhou, L.H., Santosh, M., Suo, Y.H., 2012. Mesozoic Basins in eastern China and their Bearings on the deconstruction of the North China

Li, S.Z., Zhao, G.C., Santosh, M., Liu, X., Dai, L.M., Suo, Y.H., Tam, P.Y., Song, M.C., Wang, P.C., 2012. Paleoproterozoic structural evolution of the southern segment of the JiaoLiao-Ji Belt, North China Craton. Precambrian Research 200-203, 59-73.

Li, S.Z., Zhao, S.J., Liu, X., Cao, H.H., Yu, S., Li, X.Y., Somerville, I., Yu, S.Y., Suo, Y.H., 2018. Closure of the Proto-Tethys Ocean and Early Paleozoic amalgamation of microcontinental blocks in East Asia. Earth-Science Reviews 186, 37-75.

Lin, W., Charles, N., Chen, K., Chen, Y., Faure, M., Wu, L., Wang, F., 2013b. Late Mesozoic compressional to extensional tectonics in theYiwulüshan massif, NE China and its bearing on the evolution of the Yinshan-Yanshan orogenic belt part II: Anisotropy of 
magnetic susceptibility and gravity modeling. Gondwana Research 23 (1) 78-94. https://doi.org/10.1016/j.gr.2012.02.012

521 Lin, W., Faure, M., Chen, Y., Ji, W. B., Wang, F., Wu, L., Charles, N., 2013a. Late Mesozoic compressional to extensional tectonics in the Yiwulüshan massif, NE China and its bearing on the evolution of the Yinshan-Yanshan orogenic belt part I: Structural analyses

Lin, W., Wei, W., 2018. Late Mesozoic extensional tectonics in the North China Craton and its adjacent regions: A review and synthesis. International Geology Review.

Liu, H., Martelet, G., Wang, B., Erdmann, S., Chen, Y., Faure, M., Huang, F., Scaillet, B., leBreton, N., Shu, L., Wang, R., Zhu, J., 2018. Incremental emplacement of the Late https://doi.org/10.1080/00206814.2018.1477073

Liu, J., Zhao, Y., Liu, X., Wang, Y., Liu, X., 2012. Rapid exhumation of basement rocks along Jurassic midcrustal, lopolith-like Qitianling pluton, South China, revealed by AMS and Bouguer gravity data. Journal of Geophysical Research: Solid Earth 123. https://doi.org/10.1029/2018JB015761

Ma, Y.S., Zeng, Q.L., Song, B., Du, J.J., Yang, F.Q., Zhao, Y., 2007. SHRIMP U-Pb dating of zircon from Panshan granitoid pluton in Yanshan orogenic belt and its tectonic implications. Acta Petrologica Sinica 23, 547-556 (in Chinese with English abstract).

541 Mattauer, M., Matte, P., Malavieille, J., Tapponnier, P., Maluski, H., Qin, X.Z., Lu, Y.L., Tang, 
Y.Q., 1985. Tectonics of the Qinling belt: build-up and evolution of eastern Asia. Nature 317 (6037), 496-500. https://doi.org/10.1038/317496a0

McNulty, B.A., Tobisch, O.T., Cruden, A.R., Gilder, S., 2000. Multistage emplacement of the

Meng, Q.R., Wei, H.H., Wu, G.L., Duan, L., 2014. Early Mesozoic tectonic settings of the mount givens pluton, central Sierra Nevada batholith, California. Geological Society of America Bulletin 112 (1), 119-135. https://doi.org/10.1130/00167606(2000)1122.3.CO;2 northern North China Craton. Tectonophysics 611 (1), 155-166. https://doi.org/10.1016/j.tecto.2013.11.015

Meng, Q.R., Zhang, G.W., 1999. Timing of collision of the North and South China blocks: controversy and reconciliation. Geology 27 (2), 123-126. https://doi.org/10.1130/00917613(1999)027<0123:TOCOTN>2.3.CO;2

Paterson, S.R., Fowler, T.K., Schmidt, K.L., Yoshinobu, A.S., Yuan, E.S., Miller, R.B., 1998. Interpreting magmatic fabric patterns in plutons. Lithos 44 (1-2), 53-82. https://doi.org/10.1016/s0024-4937(98)00022-x

Paterson, S.R., Vernon, R.H., Tobisch, O.T., 1989. A review of criteria for the identification of magmatic and tectonic foliations in granitoids. Journal of Structural Geology 11 (3), 349363. laccolith emplacement of the post-tectonic Vila Pouca de Aguiar granite pluton (northern Portugal): a combined AMS and gravity study. Transactions of the Royal Society of Edinburgh: Earth Sciences 91 (1-2), 123-137. https://doi.org/10.1017/s026359330000732x 
Tarling, D.H., Hrouda, F., 1993. Magnetic Anisotropy of Rocks. London, U. K.: Chapman and 566 Hall.

Vigneresse, J.L., 1990. Use and misuse of geophysical data to determine the shape at depth of granitic intrusions. Geological Journal 25 (3-4), 249-260. https://doi.org/10.1002/gj.3350250308

Wang, Y., Zhou, L., Zhao, L., 2013. Cratonic reactivation and orogeny: an example from the northern margin of the North China Craton. Gondwana Research 24 (3-4), 1203-1222. https://doi.org/10.1016/j.gr.2013.02.011

Windley, B.F., Alexeiev, D., Xiao, W., Kröner, A., Badarch, G., 2007. Tectonic models for accretion of the Central Asian Orogenic Belt. Journal of the Geological Society 164 (1),

Xiao, W., Windley, B.F., Sun, S., Li, J., Huang, B., Han, C., Yuan, C., Sun, M., Chen, H., 2015. 31-47. https://doi.org/10.1144/0016-76492006-022

Xiong, L., Wei, J., Shi, W., Fu, L., Li, H., Zhou, H., Chen, M., 2017. Geochronology, petrology

A tale of amalgamation of three Permo-Triassic collage systems in Central Asia: oroclines, sutures, and terminal accretion. Annual Review of Earth and Planetary Sciences 43 (1), 477-501. https://doi.org/10.1146/annurev-earth-060614-105254

Xu, B., Charvet, J., Chen, Y., Zhao, P., Shi, G., 2013. Middle Paleozoic convergent orogenic belts in western Inner Mongolia (China): framework, kinematics, geochronology and implications for tectonic evolution of the Central Asian Orogenic Belt. Gondwana 
Xu, Z., Lu, Y., Tang, Y., Mattauer, M., Matte, P., Malavieille, J., Tapponnier, P., Maluski, H., 1986. Deformation characteristics and Tectonic evolution of the eastern Qinling orogenic belt. Acta Geologica Sinica 60 (3), 23-35. https://doi.org/10.1111/j.17556724.1986.mp60003003.x

Yang, J.H., Sun, J.F., Zhang, M., Wu, F.Y., Wilde, S.A., 2012. Petrogenesis of silica-saturated and silica-undersaturated syenites in the northern North China Craton related to postcollisional and intraplate extension. Chemical Geology 328 (11), 149-167. https://doi.org/10.1016/j.chemgeo.2011.09.011

Ye, H., Zhang, S.H., Zhao, Y., Wu, F., 2014. Petrogenesis and emplacement deformation of the Late Triassic Dushan composite pluton in the Yanshan fold and thrust belt: Implications for the tectonic settings of the northern margin of the North China Craton during the Early Mesozoic (in Chinese with English abstract). Earth Science frontiers 21 (4), 275292.

Zhang, S.H., Zhao, Y., Davis, G.A., Ye, H., Wu, F., 2014. Temporal and spatial variations of Mesozoic magmatism and deformation in the North China Craton: implications for lithospheric thinning and decratonization. Earth-Science Reviews 131 (4), 49-87. https://doi.org/10.1016/j.earscirev.2013.12.004

Zhang, S.H., Zhao, Y., Ye, H., Hou, K.J., Li, C.F., 2012. Early Mesozoic alkaline complexes in the northern North China Craton: implications for cratonic lithospheric destruction. Lithos 155, 1-18. https://doi.org/10.1016/j.lithos.2012.08.009

Zhao, G., Wilde, S.A., Cawood, P.A., Sun, M., 2001. Archean blocks and their boundaries in the North China Craton: lithological, geochemical, structural and $\mathrm{P}-\mathrm{T}$, path constraints and tectonic evolution. Precambrian Research 107 (1) 45-73. https://doi.org/10.1016/S0301- 
Zhao, P., Chen, Y., Xu, B., Faure, M., Shi, G., Choulet, F., 2013. Did the Paleo-Asian Ocean between NCC and Mongolia Block exist during the late Paleozoic? first paleomagnetic evidence from central-eastern Inner Mongolia, China. Journal of Geophysical Research: Solid Earth 118 (5), 1873-1894. https://doi.org/10.1002/jgrb.50198

Zhao, P., Faure, M., Chen, Y., Shi, G., Xu, B., 2015. A new Triassic shortening-extrusion tectonic model for Central-Eastern Asia: Structural, geochronological and paleomagnetic investigations in the Xilamulun Fault (North China). Earth and Planetary Science Letters

Zhao, Y., 1990. The Mesozoic orogenesis and tectonic evolution of the Yanshan area. Geological Review 36 (1), 1-13 (in Chinese with English abstract).Zorin, Y.A., 1999. Geodynamics of the western part of the Mongolia-Okhotsk collisional belt, Trans-Baikal region (Russia) and Mongolia. Tectonophysics 306 (1), 33-56. https://doi.org/10.1016/S00401951(99)00042-6

Fig. 1. Simplified geological map of the Yanshan fold and thrust belt and location of the

627 Wangtufang pluton. CFSZ: Chicheng-Fengning ductile shear zone, FLSZ: Fengning-Longhua, 628 ductile shear zone, DNSZ: Damiao-Niangniangmiao ductile shear zone, UF: Unnamed fault, 629 JXT: Jixian thrust, MLYA: Malanyu anticline, XBCB: Xiabancheng basin, NDB: Niuying630 Dengzhangzi basin, WTF: Wangtufang pluton.

631 Fig. 2. Geological map and cross-sections in the Wangtufang pluton and its adjacent area.

632 Numbers in circles and stereonet show the locations and attitudes of the measured dykes, 633 respectively. U-Pb zircon data from Liu et al. (2012). See Fig. 1 for location. 
634 Fig. 3. Field photographs of the Wangtufang pluton and its country rocks. (a) Syenogranite in the

635 south of the Wangtufang pluton. (b) Diorite in the north of the Wangtufang pluton. (c) Archaean

636 gneiss in the south of the Wangtufang pluton. (d) NW-SE trending lineation in Archaean gneiss.

637 (e) Sigmoidal K-feldspar porphyroclast in Archaean gneiss, indicating a top-to-the-SE sense of

638 shearing. (f) Migmatitic granite in the north of the Wangtufang pluton.

639 Fig. 4. Field photographs of the dykes and xenoliths in the Wangtufang pluton. (a) Syenogranitic

640 dykes near the contact between the syenogranite and the diorite. (b) Dioritic xenoliths in the

641 syenogranitic dykes. (c) Syenogranitic dykes near the northeastern border of the Wangtufang

642 pluton. (d) Dioritic xenolith in the syenogranite.

643 Fig. 5. Microstructures of typical investigated samples in the Wangtufang pluton. (a)

644 Distribution map of the different types of microstructures. (b) and (c) Magmatic microstructures

645 in the syenogranite and the diorite, respectively. (d) and (e) Submagmatic microstructures in the

646 syenogranite and the diorite, respectively.

647 Fig. 6. Cathodoluminescence (CL) images and U-Pb diagrams of Concordia age of

648 representative zircons from collected samples. White solid ellipses are Secondary Ion Mass

649 Spectrometer (SIMS) U-Pb analysis locations. White dashed circles are locations of LA-MC-

650 ICPMS Hf analyses. Age and $\varepsilon H f(t)$ data are listed under individual zircons with ages ahead.

651 MSWD: mean square of weighted deviates.

652 Fig. 7. Chemical analyses diagrams of major elements for the Wangtufang pluton. (a) $\mathrm{SiO}_{2}$ vs.

$653 \mathrm{Na}_{2} \mathrm{O}+\mathrm{K}_{2} \mathrm{O}$ diagram. (b) $\mathrm{SiO}_{2}$ vs. $\mathrm{K}_{2} \mathrm{O}$ diagram. (c) Plot of A/CNK vs. ANK.

654 Fig. 8. Trace elements diagrams for the Wangtufang pluton. (a) Chondrite-normalized REE

655 patterns. (b) Primitive mantle normalized element spider patterns. 
656 Fig. 9. Diagram of $\varepsilon_{\mathrm{Hf}}(\mathrm{t})$ vs. U-Pb ages Plot of all previously analyzed zircons for U-Pb isotopes

657 in the Wangtufang pluton. Hf isotopic compositions of zircons from the contemporaneous

658 plutons are from: Yang et al. (2012); Ye et al. (2014) and Xiong et al. (2017).

659 Fig. 10. AMS scalar parameters of the Wangtufang pluton. (a) Histogram of site mean magnetic

660 susceptibility $\left(\mathrm{K}_{\mathrm{m}}\right)$. (b) Anisotropy degree $\mathrm{P}_{\mathrm{J}}$ value vs. Bulk magnetic susceptibility $\mathrm{K}_{\mathrm{m}}$. (c)

661 Shape parameter T vs. Bulk magnetic susceptibility $K_{m}$. (d) Shape parameter T vs. anisotropy

662 degree $\mathrm{P}_{\mathrm{J}}$ value.

663 Fig. 11. Magnetic mineralogy investigations of representative specimens from the Wangtufang

664 pluton. $(\mathrm{a}-\mathrm{c})$ hysteresis loops, (d-e) acquisition of isothermal remanent magnetization (IRM),

665 and $(\mathrm{g}-\mathrm{i})$ thermomagnetic curves (K (T) curves).

666 Fig. 12. Day plot of hysteresis parameters. Mrs: saturation of magnetic remanence, Ms:

667 saturation of induced magnetization, Hcr: coercivity of magnetic remanence, Hr: coercivity of

668 the measured sample. SD: single domain, PSD: pseudo-singledomain, MD: multidomain.

669 Fig. 13. Equal-area projections (lower hemisphere) of AMS results for each sampling site.

670 Confidence ellipses at 95\% level are drawn around each average orientation direction.

671 Fig. 14. Mesoscopic and magnetic fabric patterns and orientation diagrams of $K_{3}$ and $K_{1}$. (a)

672 Foliations. (b) Lineations.

673 Fig. 15. Gravity modeling. (a) Residual Bouguer gravity anomaly of the Wangtufang pluton and

674 adjacent areas after subtraction of a $200 \mathrm{~km}$ wavelength regional trend from the complete

675 Bouguer anomaly. Symbols and captions are the same as in Fig. 2. (b) 2D gravity modeling

676 across the Wangtufang pluton. Note that the arrows show the possible feeder zones for the

677 pluton.

678 Fig. 16. Block diagrams of emplacement mode of the Wangtufang pluton. 
679 Fig. 17. Triassic tectonic framework of the NCC showing Late Triassic tectonic setting of the

680 northern NCC. XBCB: Xiabancheng basin, NDB: Niuying-Dengzhangzi basin, WTF:

681 Wangtufang pluton.

682 Table 1. SIMS zircon U-Pb data of the collected samples in the Wangtufang pluton.

683 Table 2. Major- and trace-element concentrations of the Wangtufang pluton.

684 Table 3. LA-ICP-MS in-situ Hf isotopic analyses of zircons for the Wangtufang pluton.

685 Table 4. The results of AMS measurements for the Wangtufang pluton. Lat: latitude, Long:

686 longitude, $\mathrm{N}$ : the number of cylinders measured in each site, $\mathrm{K}_{\mathrm{m}}$ : mean magnetic susceptibility,

$687 \mathrm{P}_{\mathrm{J}}$ and $\mathrm{T}$ : anisotropy degree and shape parameter, respectively, $\mathrm{K}_{1}$ and $\mathrm{K}_{3}$ : magnetic lineation

688 and pole of magnetic foliation, respectively, Inc: inclination, and Dec: declination, $\alpha_{95 \max }$ and

$689 \alpha_{95 \min }$ : Jelinek's statistic confidence at 95\% level (Jelinek, 1981) in degrees, respectively. 